\title{
Siirtovaikutus opetustyössä
}

\author{
Havaintoja eräästä kokeiluhankkeesta
}

Minna Aalto

\author{
Oppimisen siirtovaikutus eli transfer voidaan aina nähdä \\ opettamisen tarkoituksena: opettaminen tähtää \\ siirrettävän ja sovellettavan tiedon muodostumiseen. \\ Artikkelissa analysoidaan yhden ammattikorkeakoulun \\ opettajien kokeiluhanketta kehittävän siirtovaikutuksen \\ kannalta. Muutoksen keskiössä on opettaja ja hänen \\ roolinsa. Missä määrin opiskelijoiden aktiivisuuden \\ vankentaminen voisi alkaa siitä, että opiskelijat voisivat \\ olla mukana opetuksen kehittelytyössä ja sen \\ suunnittelussa? kirjoittaja kysyy.
}

Opettajien yksittäiset kokeiluhankkeet ovat harvoin tulleet julkisesti dokumentoiduksi, ja sen vuoksi ne ovat jääneet yksittäisen opettajan tai oppilaitoksen omaisuudeksi (ks. Hukka 2001, 228). Erittelen Helsingin ammattikorkeakoulun tekniikan ja liikenteen toimialan opettajaryhmän opetuskokeilua. Raportti Verkkoavusteisen opetuksen kehittämisprojekti, jonka ovat kirjoittaneet opettajat Anneli Kauppinen ja Simo Silander, löytyy Helsingin ammattikorkeakoulun verkkosivuilta osoitteesta http://www.hit.fi/VAOK/raportti. Verkkoavusteisenopetuksen kehittämisprojekti-verkkoraportti on yhtenäinen selvitys erillisistä opetuskokeiluista, joita kutsutaan projekteiksi.

Projektioppiminen on nähty yhtenä ratkaisuna koulutiedon ja työelämän vaatimusten välisen tiedonsiirron ongelmaan, koska projekteissa oppimistilanteet vastaavat paremmin aitoja tilanteita, joissa eri alojen asiantuntijat ratkaisevat ongelmia (Hakkarainen \& Lonka \& Lipponen 2000, 115). Projektityöskentely nähdäänkin usein työelämän käytäntöjä toteuttavana opiskelumuotona, jota erilaiset koulutuspoliittiset työelämälähtöisyyttä korostavat ohjeet ja säännöt edellyttävät. Sääntöperustaisuus paljastuu yleensä siinä, että koulutuksessa käytössä olevia oppimistehtäviä kutsutaan projekteiksi, mutta niiden sisällössä tai toimintamuodoissa ei ole tapahtunut muutoksia. Projektityöskentely siis sisältää mahdollisuuden siirtää opiskelun painopistettä lähemmäksi työelämää, mutta se ei itsestään selvästi toteuta siirtovaikutusta eli siirrettävän ja sovellettavan tiedon muodostumista. (Ks. Lambert 2001, 98.)

Tekniikan ja liikenteen toimialalla tehtyjä opetuskokeiluja on erityisen mielenkiintoista tarkastella juuri projektityöskentelyyn sisältyvien haasteiden ja mahdollisuuksien näkökulmasta. Koska opettajien kokeiluhanke pyrkii luomaan yhteistoimintaa koulun ja työelämän välille, tarkastelen erityisesti sitä, millä tavalla Tekniikan ja liikenteen toimialalla yhteistoiminnallisesti yrityselämän kanssa toteutetut opetuskokeilut mahdollistivat siirtovaikutuksen. Oppimisen siirtovaikutus eli transfer voidaan aina nähdä opettamisen tarkoituksena: opettaminen tähtää siirret- 
tävän ja sovellettavan tiedon muodostumiseen. Kuitenkin se, mitä siirtovaikutuksella kulloinkin ymmärretään ja se, miten ja millaista siirtovaikutusta saadaan aikaan on varsin ongelmalliseksi osoittautunut tutkimuksen aihe (ks. Härkäpää 2000, 22). Erilaisia oppimiskäsityksiä edustavat suuntaukset lähestyvät siirtovaikutusta eri näkökulmasta ja sitoutuvat teoreettisesti eri suuntiin, jonka vuoksi sama ilmiö selittyy monin tavoin.

TarkastelenVerkkoavusteisenopetuksen kehittämisprojektiraporttia ns. kehittävän siirtovaikutuksen näkökulmasta. Tällöin siirtovaikutus nähdään hyödyntävän sekä koulua että työelämää. Toisin sanoen ei kehitetä vain yksittäisen oppijan tai opiskelijaryhmän valmiuksia työelämään, vaan kehittävässä siirtovaikutuksessa tähdätään vallitsevan työtoiminnan analyysiin ja sitä kautta uudenlaisiin toimintatapoihin. Kehittävän siirtovaikutuksen näkökulmasta oppiminen on toimintaympäristön muuttamista yhteisöllisessä toiminnassa. Oppimisen merkitystä ei nähdä yksilön itsensä kehittämisen välineenä, vaan oppiminen on enemmän "ilmiöiden" kehittymisen tutkimista. Samalla yksilön oppiminen on ymmärrettävissä vain yhteisön oppimisen kautta, koska yksilöt toimivat erilaisissa kokoonpanoissa tutkittavan kohteen kanssa työskennellessään. Yksilöiden välille syntyy vuorovaikutusprosessi, joka sisältää tietojen ja taitojen aktiivista yhteistoiminnallista tulkintaa, muokkaamista ja uudelleenrakentamista. Tällöin tieto nähdään yhteisöllisen toiminnan kautta muutettavana ja siirrettävänä. (Ks. Engeström 2001, 23-24; Tuomi-Gröhn 2001b, 13-14; Lambert 2001, 99; Härkäpää 2000, 25.)

\section{Tutkimusaineisto ja aineiston käsittely}

On huomionarvoista, että tekniikan ja liikenteen toimialan opettajat tekevät jatkuvasti opetuksen kehittelytyötä, mutta katsaukseni keskittyy vain yhteen kehityshankkeeseen, joka toteutettiin kevätlukukaudella 1999 ja raportoitiin sen jälkeen verkkomuotoisesti. Käytän lähteenäni opettajien kirjoittamaa Verkkoavusteisen opetuksen kehittämisprojekti -verkkoraporttia, johon viittaan lyhenteellä VAOK. Verkkoraportti on koos-

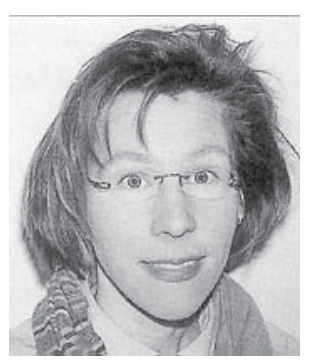

Minna Aalto

te kaikkiaan kuudesta erillisestä projektista, mutta katsaukseni keskittyy neljään päiväopiskelijoiden kanssa toteutettuun opetuskokeiluun. Päiväopiskelijoiden kanssa toteutettujen kokeilujen lisäksi Verkkoavusteisenopetuksen kehittämisprojekti-raporttiinon sisällytetty myös rakennusinsinöörien täydennyskoulutus, joka toteutettiin sekä lähiopetuksena iltaisin että verkkoavusteisena etäopiskeluna. Käytössäni on ollut tarkastelemiini kokeiluhankkeisiin osallistuneiden opiskelijoiden 14 loppuraporttia sekä yksi yrityselämän edustajan kirjoittama kirjallinen palaute. Opiskelijoiden loppuraportit sisällytettiin opetuskokeiluihin, kun opiskelijoiden edellytettiin antavan kirjallisesti palautteen uudella tavalla totetetusta kurssista sekä arvion omasta oppimisprosessistaan. Olen ryhmitellyt loppuraportit lähdeluetteloon. Olen myös haastatellut kokeilun toteuttaneita opettajia kevätlukukaudella $2001{ }^{1}$

Verkkoavusteisenopetuksen kehittämisprojektissatietotekniikkaan liittyvät ratkaisut ovat keskeinen osa opetuksen kehittelytyötä. Opetuskokeilussa tietotekniikan asiantuntijoilla, jotka ovat myös opettajia, on keskeinen rooli verkkoavusteisen oppimisympäristön luomisessa. Toinen opetuskokeilulle yhteinen lähtökohta on ongelmakeskeisen oppiminen, joka edellyttää tutkivaa asennetta, ja jonka tavoitteena on yksilön taito ohjata itse oppimistaan ja edetä vaiheittain syvenevään tiedon hallintaan. On nimittäin esitetty, että tuloksellinen toiminta kehittyvään tieto- ja viestintätekniikkaan perustuvassa työyhteisössä edellyttää työntekijöiltä hyvin kehittyneitä tiedonkäsittelytaitoja: taitoa asettaa ongelmia, luoda ja etsiä ilmiöille selityksiä, kehitellä tiedosta uusia kokonaisuuksia, verrata erilaisia käsityksiä kes- 
kenään ja arvioida niiden tueksi esitettyä todistusaiheistoa tai perusteluja (Hakkarainen \& Lonka \& Lipponen 2000, 14).

Lisäksi työelämän muutosta hahmottavien tutkimusten mukaan ryhmä- ja verkkomainen työskentely, nopea muutokseen sopeutuminen, kyky innovaatioiden ja uusien ratkaisujen kehittämiseen ovat yhä keskeisempiä yksilöiltä vaadittavia ominaisuuksia (Miettinen \& Isokangas \& Peisa 1997, 108). Tekniikan ja liikenteen toimialan opetuskokeilut olivat suunniteltu yhteistoiminnallisiksi, ja ne edellyttivät opiskelijoilta työelämän insinööreiltä vaadittavia taitoja: suunnitteluryhmässä toimimista ja tehdyn kirjallista raportointia. Kokeiluhanke toteutettiin ammattiaineiden sekä suomen kielen ja viestinnän opettajien yhteistyönä, jossa usein oli mukana myös yrityselämää edustava yhteistyökumppani.

Tarkastelemistani neljästä opetuskokeilusta kaksi toteutettiin yrityksen antaman tehtävän pohjalta ja kaksi ns. projektimuotoisesti, jolloin projektityön aihe perustui opettajan ideoimaan aiheeseen. Opettajan esittämän laajan aiheen (esim. ohjelmoinnin aiheena Internet-kaupankäynti) pohjalta synnytettiin tutkimustehtäviä, jotka kehiteltiin ja ratkaistiin opiskelijoiden muodostamissa pienryhmissä. Opiskelijat paneutuivat yrityksen antamaan tai opettajan johdolla luotuun tutkimusongelmaan ammattiaineen tunneilla luentojen, keskustelujen, yritysvierailujen ja erilaisten lähteiden avulla. Suomen kielen ja viestinnän opetuksen osuus nähtiin paljolti tutkimusraportin kirjoittamisen ja seminaarityöskentelyn ohjaamisena, mutta kurssin toteutustavasta riippuen myös erilaisten viestintätilanteiden (ryhmätyö, neuvottelutaito, julkinen esiintyminen) opastajana.

Opetuksen kehityshankkeen yksi keskeinen tavoite oli lisätä insinöörikoulutukseen oppimistehtäviä, joissa vaaditaan asioiden suhteellistamista ja laajan tietomäärän kriittistä arviointia (VAOK-raportti). Ehkä tästä johtuen tiedon kriittinen arviointi ja uuden tiedon tuottaminen näyttävät toteutetun paljolti opettajan ohjaamana. Opiskelijat kirjoittivat tutkimussuunnitelman, väliraportteja, referaatteja tutkimuskir- jallisuudesta sekä lopullisen tutkimusraportin. Viestinnän näkökulmasta uusi tieto ja sen arviointi ovat myös muodon asia: kurssilla vaadittiin asioiden esittämistä työelämässä käytössä olevien raporttimallien tapaan.

Monet oppimistehtävät edellyttivät yrityskäyntejä ja yhteistyötä tekevistä yrityksistä oli yleensä nimetty opiskelijoita varten erityinen yhteyshenkilö. Toisinaan insinööriopiskelija näytti omien yrityskontaktiensa avulla itse hankkineen kiinnostavan tutkimustehtävän pienryhmässä toteutettavaksi (ks. J.P). Asia kertoo paitsi opiskelijoiden aktiivisuudesta myös siitä, että opiskelijat ovat usein omaa insinöörialaansa vastaavissa työtehtävissä jo opiskeluaikanaan. Toisaalta työelämän ja koulun väliseen yhteistoiminnallisuuteen näyttäisi tekniikan ja liikenteen toimialalla olevan valmiuksia senkin vuoksi, että myös ammattiaineiden opettajilla on usein yrityskontakteja tai työtehtäviä yrityselämän palveluksessa. Yhdessä opetuskokeiluista oli mukana myös toinen oppilaitos (Helia). Tällöin sihteeriopiskelijat tekivät insinööriopiskelijoiden kanssa yhteistyötä hankkeessa, jonka tavoitteena oli luoda Internet-ympäristöön kuvaus Hanasaari B -lämpövoimalasta

\section{Loppuraportit} siirtovaikutuksen ilmentäjinä

Vaikka Tekniikan ja liikenteen toimialalla opetuskokeiluja toteutettiin yhdessä yrityselämän kanssa, oppiminen tapahtui paljolti koulussa. Yhteistoiminnallisuus näyttäytyy lähinnä koulussa toteutettuna pienryhmätyöskentelynä, jota opettaja ohjaa. Siirtovaikutuksen näkökulmasta onkin syytä erityisesti pohtia, missä määrin Tekniikan ja liikenteen toimialalla toteutettu projektioppiminen kehitti todellista yhteistyötä koulun ja työelämän välillä? Mikä oli projektioppimisen yhteisöllinen anti? Lisäksi voi pohtia, mikä käsitys opiskelijoille jäi heidän kehittämiensä ratkaisumallien yleistettävyyden laadusta. Kehittivätkö tehtävät heidän käsitteellistä ajatteluaan ja ongelmanratkaisukykyään?

Opettajien ja opiskelijoiden kirjoittamien raporttien perusteella vaikuttaa siltä, että yhdessä yri- 
tyselämän kanssa tehtyjä projekteja ei voi pitää todellisina yhteistyöhankkeina, joiden avulla opiskelijoiden käsitys omasta ammatillisesta osaamisestaan tai saavutettujen tietojen ja taitojen merkityksestä nousisi toiminnan keskiöön. Opetuskokeilujen merkitys kehittävän siirtovaikutuksen ilmentäjinä jäi näin ollen vähäiseksi. Kuitenkin on huomionarvoista, että opettajien asettamat kokeiluhankkeen keskeiset tavoitteet liittyivät verkkoavusteiseen oppimiseen ja ongelmakeskeiseen oppimiseen. Lisäksi lähteenä käyttämäni opiskelijoiden loppuraportti on sellaisenaan siirtovaikutusta korostamaton oppimistehtävä. Tämän vuoksi käsitystä koulussa opitun tiedon siirrettävyydestä ja sovellettavuudesta työelämään ei opiskelijoiden loppuraporttien perusteella tullut juuri esiin. Loppuraportissa opiskelijat arvioivat itseään ja kertaavat tavoitteita, joita ovat henkilökohtaisesti saavuttaneet. Tiedon ja toiminnan avulla saavutettu taito ei loppuraportin näkökulmasta fokusoidu.

Raportin kirjoittaminen on kirjallisen viestinnän harjoitus. Opiskelijoiden loppuraporttien perusteella oppimisen kohteeksi määrittyy koulutieto. Raporteissa projektioppimisen siirtovaikutus nähdään koulun suuntaan, kun projektissa opitut taidot esitetään kouluoppisen kannalta mielekkäinä: "Anturoinnin ja väylätekniikan tutkimisesta on ollut jo hyötyä, onhan anturitekniikka ja ohjausjärjestelmät meillä ihan oppiaineenakin. Projektista saadut konkreettiset esimerkit ovat auttaneet tajuamaan monia asioita kyseisten oppiaineiden tunneilla." (J.P. 16.4.99.) Palautteet myös tuovat esiin projektioppimisen annin suhteessa tavanomaiseen koulunkäyntiin. Loppuraportit kuvaavat poikkeuksetta projektioppimista positiivisena oppimiskokemuksena. Elämyksellinen oivallus tehdyn työn mielekkyydestä on sellaisenaan arvokas kehityshankkeen tulos (vrt. Hakkarainen \& Lonka \& Lipponen 2000, 205).

Loppuraportti on esimerkki konstruktivistisesta oppimiskäsityksestä, jota useat nykypäivän oppimistehtävät, harjoittelua koskevat ohjeistukset ja opetussuunnitelmat korostavat (ks. Lambert 2001, 141). Projektioppimisen hyötyjä arvioiva opiskelija ei vielä hahmota itseään ammatillisesti osaavana, vaan projektia ja siinä suo- ritettua tehtävää kuvataan yksilökehitykseen viittaavilla ilmaisuilla: "työ kasvatti itsekuria ja itsehillintää" (H.O.), "onnistuminen oli kärsivällisyyden, pitkämielisyyden ja vaikeuksien voittamisen voitto" (V.N.), "projektista saatua palautetta voi käyttää suoraan itsensä kehittämiseen" (M.T.). Kuitenkin, mikäli opiskelija toimii jo työelämässä, hän saattaa nähdä koulun ja työelämän yhdistyvän projektioppimisessa: "Allekirjoittaneen osa-aikatyössään teollisuudessa käyttämät välineet alkoivat nyt avautua aivan uudella tavalla: aiemmin syöttölaitteen toiminta oli ollut epäolennaista, nyt pumpun tuottama hydraulienergia tuntui kiehtovalta. Opiskelun ulkopuolella saadut kokemukset muuttuivat näin tutkimuksen työvälineiksi." (J.P. 16.4.99) Projektit (ja varsinkin niihin sisällytetty arvio omasta oppimisesta) tuottivat itsereflektiota ja kehittivät opiskelijan kykyjä toimia yhteistoiminnallisesti uudenlaisessa tilanteessa.

Opetuskokeiluissa pienryhmätyöskentely oli keskeisellä sijalla, ja osa opettajista olikin valmistellut toimintatapoja, joiden avulla opiskelijoiden ryhmäytyminen ja ongelman rajaus pääsivät käyntiin. Mikäli opiskelijoiden kirjoittamissa loppuraporteissa pienryhmätyöskentely mainitaan erikseen, se esitetään mieluisana ja vaivattomana. Raporteissa kuvattiin onnistunutta ryhmätyötä ja sitoutuneisuutta tehtävää ja ryhmää kohtaan. (Ks J.P 16.4.99; M.R; T.K; O.H; J.N.) On mielenkiintoista, että opiskelijoiden keskinäinen työskentelytapa ei opettajien kirjoittaman raportin mukaan sujunut ongelmitta. Ryhmätyö oli ongelmallista erityisesti silloin, jos ryhmätyötä ei ollut harjoiteltu ja opiskelijoita ei oltu opastettu tai työskentelyä ei valvottu esim. vaatimalla väliraportteja työn edistymisestä. Tästä huolimatta lähes jokaisessa ryhmässä käytiin läpi kriisivaihe, jolloin jotkut opiskelijat arvostelivat mm. työn toteutustapaa, opettajia ja olosuhteita. (VAOKraportti.) Kriisivaiheen läpikäyminen voidaan nähdä osana ryhmädynamiikan syntymistä ja siten varsin luonnollisena ilmiönä. Toisaalta opiskelijoiden taholta tullut kritiikki näyttää liittyneen uuteen toimintatapaan, jota oli vaikea sopeuttaa tavanomaiseen koulunkäyntitoimintaan. Projektityöskentely koulunkäynnin ja mahdollisen työssäkäynnin lisäksi tuotti vaikeuksia eri- 
tyisesti ns. tenttikautena. Joka tapauksessa onnistunut ryhmätyö ei syntynyt itsestään, vaan se edellytti opettajien tukea sekä opettajien tekemiä tarkkoja suunnitelmia ja aikatauluja, joista opiskelijat eivät välttämättä aina olleet tietoisia. (Vrt. VAOK-raportti.)

Tiedeyhteisön työtapoja jäljittelevä tutkivan oppimisen malli toimi kouluoppimista vankentavasti. Koska opiskelijoille kertyi itsenäiseen tutkimustyöhön vaadittavia taitoja, heidän näkökulmastaan uudella tavalla toteutetun opetuksen tavoite voidaan nähdä lähikehityksen vyöhykkeenä opinnäytetyön tekemiseen. Kehityspsykologi L. S. Vygotski tarkoittaa opiskelijoiden lähikehityksen vyöhykkeellä heidän kykyjensä ja taitojensa äärirajoilla olevaa dynaamista vyöhykettä, jolla yksilön taitojen kehittyminen tapahtuu. (Ks. esim. Hakkarainen \& Lonka \& Lipponen 2000, 81; Engeström 1998, 93.) Ajatus lähikehityksen vyöhykkeestä tuli opiskelijapalautteessa esille usein, kun opiskelijat korostivat opitun merkitystä insinöörityön tekemiselle: "Projektin läpivieminen oli ryhmälle saavutus, joka valmentaa erityisesti insinöörityön tekemiseen" (M.I.); "Projekti oli hyödyllinen ja sille oli selvä tilaus, koska se toimii hyvänä harjoituksena tulevaa insinöörityötä varten.” (A.A.); "Ajattelin projektin alusta lähtien insinöörityön kaltaisena suorituksena - Uskon, että minun on nyt paljon helpompi tehdä hyvä insinöörityö” (T.T.).

Ammattikorkeakouluille markkinoitu koulutuspoliittinen malli perustuu ajatukseen koulutuksesta, joka kestää neljä vuotta. Tekniikan ja liikenteen toimialalla tehty opetuksen kehitystyö toimii neljän vuosikurssin mallia vahvistavasti, koska opiskelijan näkökulmasta tutkimusraportin kirjoittaminen ja tutkimuksen tekemisen perusteihin paneutuminen kolmannen vuosikurssin aikana ovat askel kohti opinnäytetyötä, joka on edellytyksenä oppilaitoksesta valmistumiselle. Ajatusta opiskelijoiden lähikehityksen vyöhykkeestä tukee myös Kotilan tutkimus (2000), jonka mukaan ammattikorkeakoulun kolmannen vuosikurssin opiskelijoilla itsenäisen opiskelun mielekkyys liittyy valmistumisen läheisyyteen. Lisäksi opiskelijoille on muodostu- nut omista opiskeluistaan vastuuntunne, joka voidaan nähdä edellytyksenä itsenäisyyttä ja itseohjautuvuutta edellyttävälle opiskelulle.

\section{Kohti kehittävää siirtovaikutusta}

Pirjo Lambert (2001) on pohtinut, mitä oppimistehtäviltä tulee vaatia silloin, kun pyritään saamaan aikaan kehittävää siirtovaikutusta. Kehittävä siirtovaikutus, jolla tarkoitetaan molempia osapuolia hyödyntävää koulun ja työelämän välistä toimintaa, vaatii koululta yhteistyötä ja oppimista estävien rajojen ylittämistä sekä rajojen ylittämiseen soveltuvien välineiden kehittämistä. Ongelmakeskeisessä oppimisessa on elementtejä, joissa voidaan tuottaa uudenlaista yksilön ja yhteisön rajat ylittävää oppimista. Tällöin ongelmakeskeinen oppiminen edelleen näyttäytyy yhteistoiminnallisena ja sisältää ajatuksen tietoisesti toteutetusta pedagogisesta mallista. Kuitenkin toiminnan teorian pohjalta tutkiva oppiminen määrittyy muuttuvan työkäytännön tutkimiseksi ja oppiminen esitetään laajaksi ja vaiheittain eteneväksi sykliksi, jonka tarkoitus on muuttaa ja kehittää kokonaisten toimintajärjestelmien työkäytäntöjen. (Engeström 1998, 87-108; Lambert 2001, 110-112).

Kehittävään siirtovaikutukseen pyrkivä oppiminen vie oppimisen käytännön ongelmien ratkaisuun. Tutkiva asenne ja abstraktit käsitteet nähdään osana prosessia, jonka tarkoitus on palauttaa yhdessä luodut käsitteet ja mallit osaksi käytännön työtä, jossa niiden käyttöarvo ja merkitys myös tulevat testatuksi. Tätä kuvataan "abstraktista konkreettiseen kohoamisena", kun taas kognitiiviseen psykologiaan perustuva tutkiva oppiminen korostaa käsitteellisen ajattelun käyttöarvoa. Kehittävä siirtovaikutus siis hyödyntää kognitiivisen psykologian saavutuksia, mutta painottaa koulun ulkopuolisen elämänkäytännön merkitystä. Käsitteenmuodostamisen prosessi halutaan palauttaa osaksi niitä toimintoja, joissa käsitteet ovat syntyneet ja joissa niitä kehitetään ja käytetään. (Ks. Engeström 1998 ,100; Miettinen $2000,248,245$.) Molemmat tutkivan oppimisen mallit lähtevät vastaamaan muuttuvan työkäytännön haasteisiin, mutta kun siirtovai- 
kutusta tarkastellaan ammatillisen koulutuksen näkökulmasta, on oppimisen avulla saavutetun tiedon takaisinsiirto ja hyödyntäminen (ammatillisen) työkäytännön kehittämiseen erityisen hedelmällinen lähestymistapa.

Lambertin mukaan oppimistehtävää voidaan tarkastella välineenä, joka pyrkii saamaan aikaan todellista yhteistyötä koulun ja työelämän välille. Tällöin oppimistehtävistä voi etsiä erityisiä rajakohdeulottuvuuksia, joiden löytyminen avaa mahdollisuudet oppimistehtävien pedagogiseen kehittämiseen koulun ja työpaikan rajojen ylittäjäksi. Lambertin mukaan oppimistehtävän vaatima yleistysten laatu, jolla tarkoitetaan tehtävään sisältyvää pyrkimystä teoreettiseen yleistämiseen ja käsitteenmuutokseen, on keskeinen kehittävän siirtovaikutuksen mahdollistaja (Lambert 2001, 112). Tämänkaltaisen ulottuvuuden voi katsoa sisältyneen yrityselämän antamiin oppimistehtäviin, jotka edellyttivät yhteistoiminnallisesti toteutettua tutkivaa asennetta. Yrityselämän antamat tutkimustehtävät olivat "todellisia ongelmia", joihin odotettiin ratkaisua. Onnistuneesta tutkimustehtävän ratkaisusta on esimerkkinä materiaalitekniikan alan projektityön aihe, jossa opiskelijaryhmä sai laboratorionäytteitä tutkittavakseen. Ongelma edellytti opiskelijaryhmältä empiiristä tutkimusta ja ratkaisu vaati teoreettiseen tutkimukseen perehtymistä. Tehty tutkimus ja ratkaisuehdotus kuten myös sen itsenäinen kehittely (!) esitettiin tutkimusselosteessa, joka täytti koulun edellyttämät tutkimusraportin vaatimukset. (Ks. E.K; A.A.) Ongelmalähtöisen tutkivan oppimisen onnistumista voidaan arvioida sen perusteella, miten opiskelijat onnistuvat luomaan asteittain syvenevän tutkimusprosessin (ks. Hakkarainen \& Lonka \& Lipponen 2000, 204-205). Vaikka tutkivan oppimisen malli perustuu siirtovaikutukseen, jonka perustana nähdään tiedeyhteisön toimintaa jäljittelevä oppimisprosessi ja siihen sisältyvä abstraktien käsitteiden oppiminen, ei tutkimusraportti tai opiskelijoiden selvitystyö ole ristiriidassa työelämän vaatimusten kanssa.

Yritysten antamat laajat tehtävät olivat kuin toimeksiantoja, joista saatiin kirjallinen raportti. Opiskelijat eivät olleet mukana tutkimusongel- maa kartoittavassa keskustelussa. He eivät siis osallistuneet ongelman johtamiseen ammattikäytännön toiminnasta, vaan ongelma annettiin heille kuin irrallisena. Koska tutkimustehtävät olivat valmiiksi annettuja, eivätkä opiskelijoiden itsensä johtamia ja koska tehdyt projektit nähtiin kertasuoritteena, eikä niillä ollut jatkuvuutta, voi olettaa, että opiskelijoiden käsitys ammatillisesta osaamisestaan ei muodostunut keskeiseksi. (Vrt. Lambert 1994, 146.) Kuitenkin tutkimustehtävien ja niiden pohjalta kirjoitetun tutkimusraportin voi katsoa kannustaneen koulun ja työelämän väliseen yhteistoiminnallisuuteen. Myös työelämässä toimivat insinöörit kirjoittavat raportteja, ja tutkimusraportti on standardinomainen tekstityyppi. Lisäksi tutkimusraportti on tieteellisen tutkimuksen selostamiseen tarkoitettu muoto, joka sellaisenaan tukee teoreettisen käsitteenmuutoksen ilmaisemista.

Lambertin $(2001,113)$ mukaan oppimistehtävän representaatiomuodolla saattaakin olla olennainen merkitys kehittävän siirtovaikutuksen kannalta. Tutkimusraportti ja siihen liittyvät käytänteet (seminaari, kokoukset, ryhmätyöt) mahdollistavat kehittävän siirtovaikutuksen, koska raportti on sekä oppimistehtävä että koulun ja työelämän välisen tietojen ja taitojen ilmentäjä. Se on keskustelun kohde mm. yritysvierailuilla, seminaari-istunnoissa ja ryhmätapaamisissa. Kehittävän siirtovaikutuksen tavoitteena on saada aikaan yhteistyötä. Näin ollen oppimistehtävien tulisikin olla siten suunniteltu, että niiden varaan muodostuu riittävästi koulun ja työelämän välisiä kohtaamisen ja vuorovaikutuksen mahdollisuuksia. (Ks. Lambert 2001, 113.)

Yhteistoiminnallisuuteen kannustavien ulottuvuuksien lisäksi tavalla, jolla oppimista ohjeistetaan, on suuri merkitys kehittävän siirtovaikutuksen kannalta (Lambert 2001, 110-111). Toteutetuissa opetuskokeiluissa opettajat korostavat kontaktiopetuksen merkitystä. Uudelle opiskelumuodolle nähtiin tarpeelliseksi opettajien selkeä johtajuus, jotta toiminta olisi tuloksellista. Opettajat katsovat opiskelijoiden tarvitsevat henkilökohtaista ohjausta ja heidän mielestään projektityyppinen opettaminen edellyttää opiskelijoiden työprosessin vaiheistamista ja sen jat- 
kuvaa tukea. Tällöin opettajalla ja opiskelijoilla myös keskenään tulee olla jatkuva vuorovaikutus. Opettajan keskeinen rooli on ristiriitainen, koska kuitenkin opetuskokeilujen yhdeksi tavoitteeksi mainitaan perinteiseen kateederiopetukseen kuuluvan hierarkkisuuden murtaminen; opettajan rooli tulisi nähdä tiedon organisoijana ja tukihenkilönä. (VAOK-raportti.) Opettajat ovatkin haasteellisessa tilanteessa, kun he ovat luomassa uutta oppimisympäristöä, jonka katsotaan vaativan opettajalta suurta ohjaus- ja perehdyttämisvastuuta ja samanaikaisesti opettajat ovat ohjaamassa uudenlaiseen oppimiseeen, joka puolestaan tavoittelee mahdollisimman suurta oppilaiden itseohjautuvuutta.

Kokeiluluonteisissa projekteissa opettajan roolin keskeisyys on ymmärrettävä, koska verkkoavusteisessa opetuksessa on kyse kokonaan uudenlaisen opiskelukulttuurin vähittäisestä luomisesta. Tämä vaatii opettajalta erittäin paljon opetuksen suunnittelua, verkkokäyttöön soveltuvien oppimistehtävien rakentamista ja opetuksen tarkkaa aikatauluttamista. Kokeiluhankkeista kootussa raportissa opettajat pohtivat oppimistapahtuman luonnetta verkkoympäristössä sekä esittävät erilaisia malleja verkkoavusteisen avoimen oppimisympäristön luomiseen. Kehitystyötä tekevät opettajat ovat tietoisia didaktisista ratkaisuistaan. Heidän mukaansa verkkoavusteisen opetuksen toteuttaminen on vaativaa, koska opettaja on paljolti vastuussa uudenlaisen oppimistavan luomisesta ja toimivuudesta. (Ks. VAOK -raportti) Verkon käyttö edellyttää opettajalta tietotekniikan taitoja sekä osittain verkon varassa toteutettavaan opetukseen soveltuvan opetusmateriaalin ja oppimistehtävien valmistamista. Tämän vuoksi projekteina toteutettava opetus vie huomattavasti enemmän opettajan aikaa kuin perinteisesti luokkahuoneessa annettava opetus (vrt. Vaherva 1999, 88).

Myös ongelmalähtöisen oppimisen onnistumisen katsotaan vaativan opettajalta merkittävää ohjaavaa panosta, jonka avulla opiskelijoita rohkaistaan etsimään uutta tietoa ja kehittelemään ilmiöille selityksiä (Hakkarainen \& Lonka \& Lipponen 2000, 205).

On huomionarvoista, että Tekniikan ja liiken- teen toimialalla tehtyjen opetuskokeilujen perusteella verkko ei ole millään tavalla virtuaalinen tilana, jossa ajan ja paikan taju olisivat toissijaisia. Itse asiassa asia on päinvastoin. Opiskelumuoto edellytti aikatauluja ja opiskelijoiden ohjaamista ja heidän työskentelynsä tukemista. VAOK-raportin mukaan puhe avoimista oppimisympäristöistä on harhaa, mikäli avoimuudella tarkoitetaan opiskelijoiden itseohjautuvuutta. Vastaava havainto on saatu muista verkkopohjaisista opetuskokeiluista. Uudenlainen opiskelumuoto nostaa pedagogiset ratkaisut ensisijaisen tärkeiksi, ja itseohjautuva opiskelu vaatiikin ensisijassa ohjausta, eikä missään tapauksessa vähennä sen tarvetta. (Ks. Pasanen 2001, 53.)

Tehdyt opetuskokeilut tekevät selväksi, että opettajien projektimuotoisen opetustyön suunnitteluun ja opetuksen ohjaukseen käytetty aika ylittää monikertaisesti perinteisen koulunkäyntitoiminnan tuntimäärät. Kaikenlaisen opetustyön kehittämisen hankaluudeksi nimetäänkin pääsääntöisesti oppilaiden ohjaukseen käytettävän ajan puute (ks. Hukka 2001, 242). Sen lisäksi, että projektityöskentely vaatii opettajilta erittäin voimakasta sitoutumista työhön, projektityöskentelyn on oltava pitkäjännitteistä, ja sen katsotaan edellyttävän työyhteisöjen kannustusta ja koulun johdon vahvaa tukea. (Vrt. TuomiGröhn 2001a, 63-64.)

Pirjo Lambertin mainitsemista neljästä oppimistehtävän rajakohdeulottuvuudesta erityisesti tehtävän yleistysten laadulla sekä tehtävän representaatiomuodolla on vahvat rajakohdeulottuvuudet, joiden avulla voidaan saada aikaan kehittävää siirtovaikutusta. Tutkimustehtävät olisivat voineet sisältää enemmän yhteistoiminnallisuuteen kannustavia ulottuvuuksia. Myös tapa, jolla oppimista ohjeistettiin, näyttää sisältävän niukasti kehittävän siirtovaikutuksen mahdollisuuksia. Oppiminen tapahtui paljolti koulussa opettajan johdolla ja yhteistoiminnallisuus toteutui opiskelijoiden pienryhmätyöskentelynä.

Toteutetuissa projekteissa todellinen yhteistyö yrityselämän kanssa näyttää jääneen vähäiseksi. Näin ollen voidaan pohtia, millä keinoin yhteistoiminnallisuutta yrityselämän ja opiskelijoi- 
den välillä olisi voitu kehittää. Pohdin lopuksi toteutettujen opetuskokeilujen kehittämisen mahdollisuuksia yhteisöllisen oppimisen näkökulmasta ja sitä, millä tavalla verkko voi avustaa siirtovaikutuksen aikaansaamista. Onko oppimistehtävien kehittävään siirtovaikutukseen pyrkiviä rajakohdeulottuvuuksia mahdollista kehittää verkkoavusteisen opetuksen keinoin?

\section{Yhteisöllisen oppimisen mahdollisu usia}

Tekniikan ja liikenteen toimialalla opettajat toteuttavat kehityshankkeensa yhteistoiminnallisesti, jolloin eri alojen opettajat pystyvät hyödyntämään toistensa asiantuntemusta. Mikäli verkkoavusteinen opetus saadaan vallitsevaksi käytännöksi ja, kuten opettajat toivovat, vaiheittain eteneväksi koulukulttuurin muutokseksi, voitaneen myös miettiä, miten opiskelijoiden yhteistoiminnallisuutta voitaisiin tukea ja miten saada aikaan todellista yhteistyötä työelämän ja koulun välillä. Kehittävän siirtovaikutuksen näkökulmasta voi pohtia, olisiko esimerkiksi verkkokeskustelun aktivointi ja kirjallisen opponoinnin vaatimus saanut aikaan keskusteluyhteyden, joka olisi myös yltänyt yrityksiä ja yhteisöjä edustavien yhteistyökumppaneiden tietoon. Ylipäätänsä olisiko avoin verkko kiinnostanut myös työelämää edustavia yhteistyökumppaneita? Yrityselämän yhteistyökumppaneilla olisi ollut tilaisuus seurata, miten opiskelijat työstävät ongelmaa. He olisivat saattaneet halutessaan kommentoida opiskelijoiden keskeneräisiä töitä. Dialogi olisi voinut saada aikaan todellista yhteistyötä koulun ja työelämän välille, ja samalla se olisi jakanut opettajien ohjausvastuuta ja mahdollisesti kannustanut opiskelijoita itseohjautuvuuteen. Lisäksi verkkoavusteinen opetus olisi saattanut sopia erityisen hyvin työelämän edustajille, koska kirjallinen kommentointi ei ole sidottu aikatauluihin tai tapaamisaikoihin, joiden noudattaminen saattaa työelämän kiireen vuoksi muodostua hankalaksi.

Verkkopohjaisen opetuksen yhteydessä on havaittu, että verkossa käytävän kirjallisen keskustelun avulla voidaan luoda keskustelukanava, jossa vuorovaikutus ei kulje opettajan johdolla ja opet- tajan kautta. Tutkimusten mukaan verkossa opiskelijoiden aktiivisuus jakautuu tasaisemmin kuin luokassa ja myös hiljaisemmatkin opiskelijat "ehtivät" mukaan keskusteluun. Ennen kaikkea verkkokeskustelun on havaittu olevan rakentavaa, koska kirjallinen pohdiskelu tukee ajatusten syvällistä pohtimista ja erilaisten näkökulmien vertailemista. Toisten kirjallisten ajatuskulkujen kommentoiminen on myös älyllisesti vaativaa, koska se edellyttää heidän ajatuskulkujensa ja ongelmanratkaisun jäljittämistä. (Ks. Hakkarainen \& Lonka \& Lipponen 2000, 160-161.) Selittämisen ja kirjoittamisen on katsottu tukevan oppimista ja olevan erittäin tehokas keino silloin, kun konkreettisiin kokemuksiin ja esimerkkeihin yhdistetään abstrakti teoreettinen ajattelu. Monimutkaisten taitojen oppimisessa paras tulos saavutetaan vuorottelemalla ryhmätyön ja yksilöllisen harjoittelun välillä. Siirtovaikutuksen merkitys ja voimakkuus riippuu kyseessä olevan tiedon ja taidon luonteesta. (Hakkarainen \& Lonka \& Lipponen 2000, 155.)

Opiskelijoiden loppuraporttien perusteella pienryhmien jäsenet joutuivat selittämään toisilleen mahdollisina pitämiään ongelmanratkaisuja jo varsin varhaisessa vaiheessa, koska laajat tutkimustehtävät edellyttivät tarkkaa tehtävänrajausta ja olennaisen etsintää. Ainakin jossain määrin kaikki ryhmäläiset tutustuivat toistensa tuotoksiin, koska esitelmät pidettiin ryhmätyönä. Se edellytti asiakokonaisuuksien keskinäisten suhteiden selventämistä ja tehtävänjakoa. Kuitenkin opiskelijoiden ryhmätyön osuus jäi varsin vähäiseksi. Joissain ryhmissä jäsenet tapasivat vasta juuri ennen loppuseminaaria ja sopivat tehtävänjaosta, jonka avulla yksilösuoritteista koottiin yhteinen projekti (ks. J.M; P.S.). Vain yhdessä loppuraportissa mainitaan pienryhmän jäsenten lukeneen ja kommentoineen toistensa keskeneräisiä tekstejä (ks. J.N.).

Kehittävän siirtovaikutuksen näkökulmasta itse työprosessin edelleen kehittäminen niin, että opiskelijoita erityisesti kannustettaisiin ja ohjattaisiin ryhmätyöhön eli sosiaalisessa vuorovaikutuksessa tapahtuvaan projektityöskentelyyn, olisi mielekästä. Tällöin työelämän käytännön ja opiskelijoiden koulutiedon tai teoreettisen läh- 
dekirjallisuuden yhdistäminen mahdollistaisi siirtovaikutuksen, jossa opiskelijoiden yhteistoiminnallisuudella olisi keskeinen sija. Verkkoavusteisesti toteutetuissa projekteissa olisi ollut teknisesti varsin helppo jakaa opiskelijoiden kommentoitavaksi keskeneräisiäkin oppimistehtäviä, mutta kysymys on myös kulttuurisesta käytänteestä. Keskeneräisten töiden kommentointi edellyttäisi opponoinnin olevan yleinen ja itseohjautuvasti toteutettu menettely sekä yleisesti hyväksytty tapa. Tällä hetkellä osana koulunkäyntitoimintaa opiskelijat vetäytyvät usein kommentoinnista, koska he kokevat varsinkin eriävien mielipiteidensä, mutta myös erilaisten ajatusten esittämisen konflikteina. Toisinaan kommentointi nähdään työläänä ja vaativana. Opiskelijat vetoavat kiireeseensä; he eivät ehdi eivätkä uskalla olla toistensa tekstien lukijoita.

Näin ollen verkossa mahdollinen vuorovaikutteisuus ei itsestään selvästi tue opiskelua, vaan keskusteluun tulee rohkaista ja kannustaa. Tekniikan ja liikenteen toimialan opettajat katsoivat tärkeäksi opiskelijoiden perehdyttämistä verkkomuotoiseen opiskeluun: opiskelijat, jotka heti projektin aluksi saivat perehdyttämistä tietoverkon käyttöön, olivat aktiivisempia verkon käytössä kuin ne, joiden tietoverkon käyttötaidot jäivät oman harjoittelun varaan. Verkon käyttö aina edellytti opettajalta opiskelijoiden sopeuttamista uudenlaiseen aktiivisuutta edellyttävään työtapaan. Ajatus kokonaan verkon varassa tapahtuvasta ammatillisesta opiskelusta on kokeiluun osallistuneilla opettajille vieras. Heidän mukaansa opiskelijat tarvitsevat ja haluavat olla henkilökohtaisesti tekemisissä opettajansa kanssa. Lisäksi ryhmähengen luominen verkkoon on vaikeaa. (Ks. VAOK-raportti.)

Opiskelijat kokivat projektimuotoisen työskentelytavan ja vertaisryhmälle esiintymisen mielekkäänä. Tämä käy erityisen hyvin ilmi materiaalitekniikan ja virtuaalivoiman opetuskokeiluihin osallistuneiden opiskelijoiden loppuraporteista, joissa he mainitsevat seminaarimuotoisesti järjestetyn projektien tulosten esittelypäivän erityisen antoisana. Opiskelijatovereiden esityksiä ja tehtyjen projektitöiden selostuksia kuunneltiin mielellään ja kiinnostuneina. Niin ikään opponointia arvostettiin tehokkaana tapana tehdä kiinnostava vuorovaikutteinen esitys. Opponointi myös teki esitelmöitsijät tietoisiksi omista tiedoistaan ja osaamisestaan. Positiivinen palaute kertoo siitä, että opiskelijoilla on kiinnostusta toistensa työn arviointiin ja sitä kautta he voivat (kuten opiskelijoiden loppuraporteista käy ilmi) vahvistaa käsityksiin omasta osaamisestaan sekä tuotetun tiedon tarpeellisuudesta.

Tehdyt opetuskokeilut todistavat, että opiskelijoilla on valmiuksia itsenäiseen tutkimusluonteiseen työhön ja pienryhmissä tapahtuvaan oppimistoimintaan. Olisiko projektityyppistä oppimista syytä lisätä vaiheittain niin, että sen nivominen osaksi koulunkäyntitoimintaa ei tuottaisi vaikeuksia? Tällöin projektioppimisen vaatimia taitoja (erityisesti itseohjautuvuutta) voisi vähitellen lisätä, eikä opettajan ohjausvastuu muodostuisi kohtuuttomaksi. Opettajan roolin muuttuminen vähemmän tärkeäksi saattaisi mahdollistaa myös kehittävän siirtovaikutuksen. Mikäli opiskelijat saavuttavat itseohjautuvuuden taitoja ja tulevat tietoiseksi projektityönsä ammatillisesta merkityksestä ja käyttöarvosta, heillä saattaa olla valmiuksia toimia koulun ja työelämän välisen tiedonsiirron agentteina. Tähän on jo tehtyjen opetuskokeilujen perusteella olemassa mahdollisuuksia, koska työelämässä toimivat opiskelijat olivat itse keksineet tutkimustehtävän projektimuotoisesti yrityselämän kanssa toteutettavaksi. Missä määrin opiskelijoiden aktiivisuuden vankentaminen voisi alkaa siitä, että opiskelijat voisivat olla mukana opetuksen kehittelytyössä ja sen suunnittelussa? Myös tämänkaltaiseen yhteistyöhön opiskelijoilla näyttäisi olevan valmiuksia, koska opiskelijapalautteessa on parannusehdotuksia ja ideoita projektioppimisen kehittämiseen.

Lisäksi voi pohtia, millä tavalla opiskelijoiden valmiuksia voisi kehittää niin, että heillä olisi uskallusta lähestyä työelämän edustajia ja esittää omaan tutkimukseensa liittyviä kysymyksiä. Opiskelijoille olisi tarkoituksenmukaista opettaa valmiuksia yhteistoiminnallisuuteen projektioppimisen avulla ja sen ohessa. Projektioppimiseen onkin joissain kokeiluhankkeissa yhdistetty viestinnän kurssi, jolla keskitytään esiintymistaidon, 
neuvottelu- ja ryhmätyötaitojen kehittämiseen. Olisi luontevaa, että kyseinen opetus tapahtuisi mahdollisimman paljon osana projektinomaista oppimista, jolloin esiintyminen ja neuvottelutaidot asettautuisivat työvälineiksi. Tällöin opiskelijoille saattaisi myös kehittyä tietoisuus siitä, että kaikkeen ryhmässä tapahtuvaan toimintaan liittyy suunnittelu ja ohjaus. Lisäksi esiintyminen ja ryhmätyötaidot näyttäisivät "todellisissa" oppimistilanteissa paitsi taidoilta, jotka ovat erittäin tärkeitä työssä selviytymisen välineitä, myös taidoilta, jotka ovat kaikkien opittavissa.

\section{Lähteet}

ENGESTRÖM, Y. (1998), Kehittävä työntutkimus. Perusteita, tuloksia ja haasteita. Helsinki: Edita.

ENGESTRÖM, Y. (2001), Kehittävä siirtovaikutus: mitä ja miksi? - Koulun ja työn rajavyöhykkeellä. Uusia työssä oppimisen mahdollisuuksia. Toim. Tuomi-Gröhn, K. \& Engeström, Y. Helsinki: Yliopistopaino.

HAKKARAINEN, K. \& Lonka, K. \& Lipponen, L. (2000), Tutkiva oppiminen. Älykkään toiminnan rajat ja niiden ylittäminen. Helsinki: WSOY.

HUKKA, K. (2001), Oppimiskumppanuus - uudenlaisen yhteistoiminnan mahdollisuus oppilaitoksen ja työelämän välillä. - Koulun ja työn rajavyöhykkeellä. Uusia työssä oppimisen mahdollisuuksia. Toim. Tuomi-Gröhn, K. \& Engeström, Y. Helsinki: Yliopistopaino.

HÄRKÄPÄÄ, L. (2000), Neuvotellen yhteistoimintaan, ei anellen eikä sanellen. Kehittämisraportti työssäoppimisesta. Helain julkaisusarja C, 1:2000. Helsinki: Helia Ammatillinen opettajakorkeakoulu.

KAUPPINEN, A. \& Silander, S., Verkkoavusteisen opetuksen kehittämisprojekti. Helsingin ammattikorkeakoulu, Tekniikan ja liikenteen toimiala. http:/ /www.hit.fi/VAOK/raportti. Luettu joulukuussa 2000 .

KOTILA, H. (2000), Ammattikorkeakoulun opiskelijoiden kokemuksia opetussuunnitelmasta. Helsinki: Helsingin yliopiston opettajankoulutuslaitos. Tutkimuksia 214.

LAMBERT, P. (1994), Terveydenhuolto-oppilaitoksen opettajien työn kehittäminen: Kehittävän työntutkimuksen sovellus ammatillisessa opettajankoulutuksessa. Helsinki: Educa.

LAMBERT, P. (2001), Oppimistehtävät kehittävän siirtovaikutuksen tuottajina. Koulun ja työn rajavyöhykkeellä. Uusia työssä oppimisen mahdollisuuksia. Toim. Tuomi-Gröhn, K. \& Engeström, Y. Helsinki: Yliopistopaino.

MIETTINEN, R. \& Isokangas, J. \& Peisa, S. (1997), Yrityksen perustamisen ja toiminnan tutkiminen Partneriyrityksen käyttö kaupallisessa koulutuksessa. Työn muutos ja oppiminen. Aikuiskasvatuksen 38. vuosikirja. Kansanvalistusseura ja Aikuiskasvatuksen tutkimusseura.
MIETTINEN, R. (2000), Konstruktivistinen oppimisnäkemys ja esineellinen toiminta. Aikuiskasvatus 4/2000.

PASANEN, H. (2001), Itseohjautuvuus aikuiskoulutuksessa. Aikuiskasvatus 1/2001.

TUOMI-GRÖHN, T. (2001a), Kehittävä siirtovaikutus koulun ja työpaikan yhteistyön tavoitteena - tapaustutkimus lähihoitajien lisäkoulutuksesta. Koulun ja työn rajavyöhykkeellä. Uusia työssä oppimisen mahdollisuuksia. Toim. Tuomi-Gröhn, K. \& Engeström, Y. Helsinki: Yliopistopaino.

TUOMI-GRÖHN, T. (2001b), Työssäoppiminen ja kehittävä siirtovaikutus koulun ja työn sillanrakentajana. - Koulun ja työn rajavyöhykkeellä. Uusia työssä oppimisen mahdollisuuksia. Toim. TuomiGröhn, K. \& Engeström, Y. Helsinki: Yliopistopaino.

VAHERVA, T. (1999), Henkilökoulutuksen rajat ja mahdollisuudet. - Oppiminen ja asiantuntijuus. Työelämän ja koulutuksen näkökulmia. Toim. Eteläpelto, A. \& Tynjälä, P. Helsinki: WSOY.

\section{Painamattomat}

Materiaalitekniikan opetusokeilujen loppuraportit: A.A. = Raportti työprosessista 5.5.1999.

E.K. = Materiaalitekniikan projektityö 8.9.1999.(työelämän edustajan raportti).

J.N. = Materiaalitekniikan projektin loppuraportti 4.5.1999.

J.P. = Raportti työprosessista (päiväämätön).

V.N. = Johdatus tutkimukseen. Materiaaliteknii kan projekti, loppuraportti 1999.

Virtuaalivoimala-projektin loppuraportit:

H.O. = Virtuaalivoimala -raportti 28.4.1999.

M.K. = Tutkimusraportti. Virtuaalivoimala (päiväämätön).

P.I. = Raportti työprosessista 28.4.1999.

Ohjelmistotekniikan projektityön loppuraportit: J.M. = Raportti 27.4.1999.

M.R. = Raportti työprosessista (päiväämätön).

P.S. = Raportti 30.4.1999.

T.K. = Raportti 3.5.1999.

T.T. = Ohjelmistotekniikan seminaarista 2.5.1999.

Hydrauliikan projektitöiden loppuraportit:

J.P. = Hydrauliikan projektin analysointi 16.4.1999.

M.I. = Johdatus tutkimukseen. Hydrauliikan projekti, loppuraportti 1999.

\section{Viite}

Kiitän Tekniikan ja liikenteen toimialan yliopettaja Anneli Kauppista sekä Helian yliopettajia Leena Härkäpäätä sekä Pirjo Lambertia monista käsikirjoitusta rakentavista kommenteista ja kannustuksesta. Katsaukseni on syntynyt Helian opettajakorkeakoulussa tehdyn siirtovaikutusta käsittelevän seminaarityön ja Tekniikan ja liikenteen toimialalla tehdyn opetusharjoittelun innoittamana.

Artikkeli saapui toimitukseen 16.5.2001. Se hyväksyttiin julkaistavaksi toimituskunnan kokouksessa 3.9.2002. 